\title{
Article \\ Drivers of Land Use Conflicts in Infrastructural Mega Projects in Coastal Areas: A Case Study of Patimban Seaport, Indonesia
}

\author{
Roni Susman ${ }^{1, * \mathbb{D}}$, Annelie Maja. Gütte ${ }^{2}$ and Thomas Weith ${ }^{2}$ \\ 1 Institute of Environmental Sciences and Geography, University of Potsdam, 14469 Potsdam, Germany \\ 2 Leibniz Centre for Agricultural Landscape Research (ZALF), 15374 Müncheberg, Germany; \\ annelie.guette@web.de (A.M.G.); thomas.weith@zalf.de (T.W.) \\ * Correspondence: susman@uni-potsdam.de
}

check for

updates

Citation: Susman, R.; Gütte, A.M.; Weith, T. Drivers of Land Use Conflicts in Infrastructural Mega Projects in Coastal Areas: A Case Study of Patimban Seaport, Indonesia. Land 2021, 10, 615. https://doi.org/ 10.3390/land10060615

Received: 28 April 2021

Accepted: 4 June 2021

Published: 8 June 2021

Publisher's Note: MDPI stays neutral with regard to jurisdictional claims in published maps and institutional affiliations.

Copyright: (c) 2021 by the authors. Licensee MDPI, Basel, Switzerland. This article is an open access article distributed under the terms and conditions of the Creative Commons Attribution (CC BY) license (https:/ / creativecommons.org/licenses/by/ $4.0 /)$.

\begin{abstract}
Coastal areas are particularly sensitive because they are complex, and related land use conflicts are more intense than those in noncoastal areas. In addition to representing a unique encounter of natural and socioeconomic factors, coastal areas have become paradigms of progressive urbanisation and economic development. Our study of the infrastructural mega project of Patimban Seaport in Indonesia explores the factors driving land use changes and the subsequent land use conflicts emerging from large-scale land transformation in the course of seaport development and mega project governance. We utilised interviews and questionnaires to investigate institutional aspects and conflict drivers. Specifically, we retrace and investigate the mechanisms guiding how mega project governance, land use planning, and actual land use interact. Therefore, we observe and analyse where land use conflicts emerge and the roles that a lack of stakeholder interest involvement and tenure-responsive planning take in this process. Our findings reflect how mismanagement and inadequate planning processes lead to market failure, land abandonment and dereliction and how they overburden local communities with the costs of mega projects. Enforcing a stronger coherence between land use planning, participation and land tenure within the land governance process in coastal land use development at all levels and raising the capacity of stakeholders to interfere with governance and planning processes will reduce conflicts and lead to sustainable coastal development in Indonesia.
\end{abstract}

Keywords: infrastructural mega projects; land use conflicts; land tenure; land use planning; Patimban Seaport

\section{Introduction}

Dealing with questions of land use has evolved into one of the most important issues in the Anthropocene era-especially with regard to the societal demand to solve existing and upcoming land use conflicts [1-3]. Coastal areas are particularly sensitive because they are more complex, and their related land use conflicts are more intense than in noncoastal areas [4]. They represent a unique encounter between natural and socioeconomic factors. Numerous and diverse stakeholders rely on coastal resources. However, due to the limited supply of coastal land, "alternatives for expansion and substitution are necessarily limited" [1-3]. In particular, coast-dependent economic activities, such as the operation of seaports or desalination and power plants, compete with touristic and residential development as well as with environmental and agricultural interests $[5,6]$. Additionally, with regard to the planning, implementation and governance of coastal zone infrastructural megaprojects, there are links of coastal zone management to terrestrial and marine spatial planning, e.g., in terms of wider hinterland dynamics $[4,5]$ or offshore wind energy production and deep seaports [7-10].

Infrastructural mega projects-especially in congested areas-frequently superpose the sensitivity of coastal areas as multifunctional landscapes. Policy makers largely consider 
the potential of such projects as growth poles [11,12] and thus tend to neglect regional and local interests and specificities, spurring the emergence of land use conflicts $[11,13]$. This nexus is of specific relevance in emerging countries of the global south, such as in Indonesia, which serves as the context of this case study.

Coastal and marine resources are of increasing strategic significance for the transitional process in Indonesia's development [14,15]. Given the aim of fostering the country's significance along the international maritime axis [15], the development of port infrastructure is of major relevance. Despite its significance, Indonesia has, however, not yet managed to establish a coherent integrated coastal and marine management $[12,15,16]$. Instead, legal pluralism prevails [17] in which land use and development plans as well as state regulatory systems and traditional tenure arrangements overlap and collide across sectors, communities of interest and administrative levels [12,15-20]. The result is frequently represented in project rejection $[11,21,22]$, poor project performance [11,23-25], and erupting land use conflicts $[11,23]$.

Not least because of these results, several scholars have stressed the need for participatory approaches, (secondary) stakeholder involvement, and dispute resolution mechanisms in the context of development projects $[5,11,21-24]$. Although it is broadly discussed in research, those concepts remain barely cultivated in practice. Stakeholder participation frequently takes into account primary stakeholders but not secondary stakeholders, such as local communities $[5,11,17,22-24]$, although research has pointed out the significance of local communities' involvement for project performance and outcomes [22,24,25].

Participatory approaches not only have the potential to increase project legitimacy and solve project-related conflicts of goal incongruence in terms of land and resource use by means of negotiation, compensation and interest synchronisation [11,22], but can also be meaningful with regard to revealing de facto tenure arrangements as indirect sources of land use conflicts that exceed narrow project boundaries and contexts $[17,23,26]$. Referring to the latter, research has also pointed out the relevance of tenure-responsive land use planning [20,27-29]. Although acknowledged as a major source of land use conflicts, land tenure arrangements are rarely discussed or taken into account within project development and land use planning.

Thus, we argue that coastal zone management in countries of the global south faces issues of legal pluralism and land competition that can result in land use conflicts. Meanwhile, it should be noted that governance regimes in mega project infrastructure development have the potential to either stimulate or reconcile those conflicts $[23,26]$. Spatial planning is considered a major instrument for controlling land development and preventing land use conflicts. In the context of the Patimban Seaport project in Indonesia, we nonetheless observe the occurrence of severe land use conflicts. Likewise, the sources of land use conflicts observed in this study have been observed before. In this paper, however, we analyse in a case-specific and holistic context the origin and interrelation of land use conflicts in the decision process by retracing how the project governance process interacts with provincial and municipal spatial planning. Based on the argumentation above, we pay particular attention to the role of stakeholder involvement and land tenure arrangements within the project process and observe how those factors interact in their potential to spur or settle land use conflicts. Although land use conflicts may also be induced or at least intensified by natural drivers (e.g., climate change, land scarcity), this paper therefore focuses on human-induced drivers of land use conflicts.

We next provide an overview of current conceptual discourses as a basis of our analysis. As the Patimban Seaport project represents the focal point of our analysis and as we analyse the interrelation of concepts that are each by themselves relatively well explored, we focus on current debates of those concepts in an Indonesian context rather than drawing cross-country comparisons. For the same reason, we prepend the case study context prominently to introduce the project and land-related developments in the area as an individual subsection. The ensuing section outlines the overall research design and provides insights into data collection and analytical methods. Subsequently, we present the 
results of our analysis, which are further discussed with regard to policy implications and future research opportunities. The conclusion sums up the paper's findings and transmits the key insights of this paper.

\subsection{Concepts for Analysis}

The analysis of land use changes is currently an essential component of land use sciences [30]. Globally, a trend towards artificial land uses is observable [31,32], and consequently, land use conflicts occur. Following von der Dunk et al.'s general definition, land use conflicts arise "whenever land use stakeholders (=conflict parties) have incompatible interests related to certain land use units (=geographical component). The incompatible interest results from negative effects (=conflict issues) emitted by the land use unit under question" [33]. Since we focus on planning and governance processes, we also cite Kaswamila and Songorwa's specific understanding of land use conflicts as referring "to disputes over the use of land and other natural resources contrary to designated use(s) in a village land use plan" [34].

Infrastructural mega projects are a major source of emerging land use conflicts in the context of land use changes. To date, research in this field, including that with a particular focus on coastal zone management, has focused on urbanisation and economic development processes [11,21,22,24,35-41]. However, infrastructural mega projects are most often analysed from a technical or managerial perspective and within the field of planning studies [21,35-40]. Less importance is given to the wider implications for local communities and the regional impacts of mega projects, such as their socioeconomic effects in terms of land use changes and the emergence of land use conflicts [21,24].

An initial shift from an on-site project research focus towards the consideration of wider socioeconomic hinterland dynamics tackling land use changes and land governance in the context of telecoupling studies can be observed [5,38,42,43]. For Indonesia, Felsenstein et al. [5] analyse regional interrelations and the emergence of land use conflicts in the context of port development (see also $[5,17,19,36,44])$. In particular, these infrastructural mega projects are criticised for spurring conflicts, since their benefits for local communities are limited, i.e., considering potential environmental degradation, loss of livelihood, and displacement $[5,21,22,45]$. Thus, project promoters, as primary stakeholders, such as project investors, coordinators, or developers, call for the maximisation of internal benefits, while the public calls for external benefits $[5,46]$. This demonstrates that distinct communities of interest pursue highly diverging agendas [37], whereby local communities as secondary stakeholders obtain much less power and influence within project governance processes [21,22]. Adequate participation schemes are frequently lacking in top-down implemented mega projects, while specific local stakeholder groups are marginalised within the process [47,48].

Corresponding to the general development outlined above, Indonesia registers high rates of land conversion. Particularly, in the context of urban growth and economic development, large areas of agricultural land, forests, and land designated for conservation efforts have been converted into industrial estates and urban land [12,18,49-52]. Land use change-related conflicts are largely rooted in informal and weak tenure arrangements and the Indonesian land management system, which incorporates a highly pluralistic and fragmented legal system of land tenure and land use administration that is majorly shaped by the dualism of customary (adat) law and statutory law, with more than 600 overlapping regulations [53-55]. This phenomenon of overlapping and conflicting statutory and customary law spurring land use conflicts, particularly with regard to informal tenure arrangements and indigenous land rights, is observable in many countries of the global south and the global north [56-58].

Although the legal framework for land management formally integrates modern law and customary tenure systems [20,53-56], large uncertainties regarding property rights prevail in practice [20]. In particular, the right of ownership is of uttermost relevance in land governance-related questions, such as the granting of land development permits or 
the negotiation of land transfers and compensation [20]. In this context, it must be noted that Indonesia's system of land governance at least formally considers landowners and strives for deliberate and mutual negotiations within land acquisition processes [18,26]. However, referring to land status only does not take into account all those who are aligned with land plots on a customary basis, such as informal tenants or cultivators [17,26].

With regard to informality, an unclear and weak tenure system based on customary law places local communities in a weak position in terms of rights enforcement $[17,20]$. An ongoing scientific debate discusses the relevance of options to enhance tenure security $[18,19,21,22,25,53,57,58]$. However, the formalisation of tenure through conventional means of land registration and land titling programmes often fails to strengthen the rights of informal tenants due to a lack of public agency capacity $[57,58]$ and efforts frequently resulting in upward filtration $[18,19,53,57,58]$. Thus, weak tenure arrangements and legal pluralism pave the way for political arbitrariness and selective law enforcement, which is particularly evident in Indonesian practices of land management and planning [20,53,59].

These issues become most evident with regard to discrepancies in Indonesian land use plans and actual land use [60]. The effectiveness of spatial planning tools, such as the designation of land use plans and the land development permit system, aiming to control land development and anticipate land use conflicts, is undermined by frequent argumentation that development should not confirm to land use plans "but the plan itself should be adaptable to market demands" [18,19,50]. Hudalah et al. [19] found this neoliberal argument to be used as justification to revise land use plans, which then in turn serve as legal justification for authorities and investors to clear land. Although Reerink [53] finds that land clearance is still rare as a single enforcement measure and that legislation is issued for more protection and compensation, ineffective monitoring and enforcement mechanisms undermine those efforts, such that land owners and aligned users have, de facto, no other choice than to sell and leave the land [18]. Dhiaulhaq et al. [17] summarise this development in terms of "state or corporate actors gain[ing] control over large tracts of land, neglecting the pre-existing and de facto land rights of local communities' local land rights" [17].

In our case study analysis of the Patimban Seaport project, we retrace and investigate those mechanisms of how mega project governance, land use planning and actual land use interact. Thereby, we observe and analyse where land use conflicts emerge and which role a lack of stakeholder interest involvement and tenure responsive planning takes in this course.

\subsection{Case Study Context}

The Patimban Seaport is located in Subang Regency in West Java Province (see Figure 1). Subang Regency can be considered a growth region: in 2019, the population had increased to 1.6 million inhabitants [61]. With $63 \%$ of the population being aged below 15 years and ever-expanding levels of infrastructure and accessibility, the region represents one of the top ten investment destinations in West Java [62]. The region's gross domestic income per capita per annum has steadily increased from USD 1180 in 2016 to USD 1300 in 2018 [63]. 


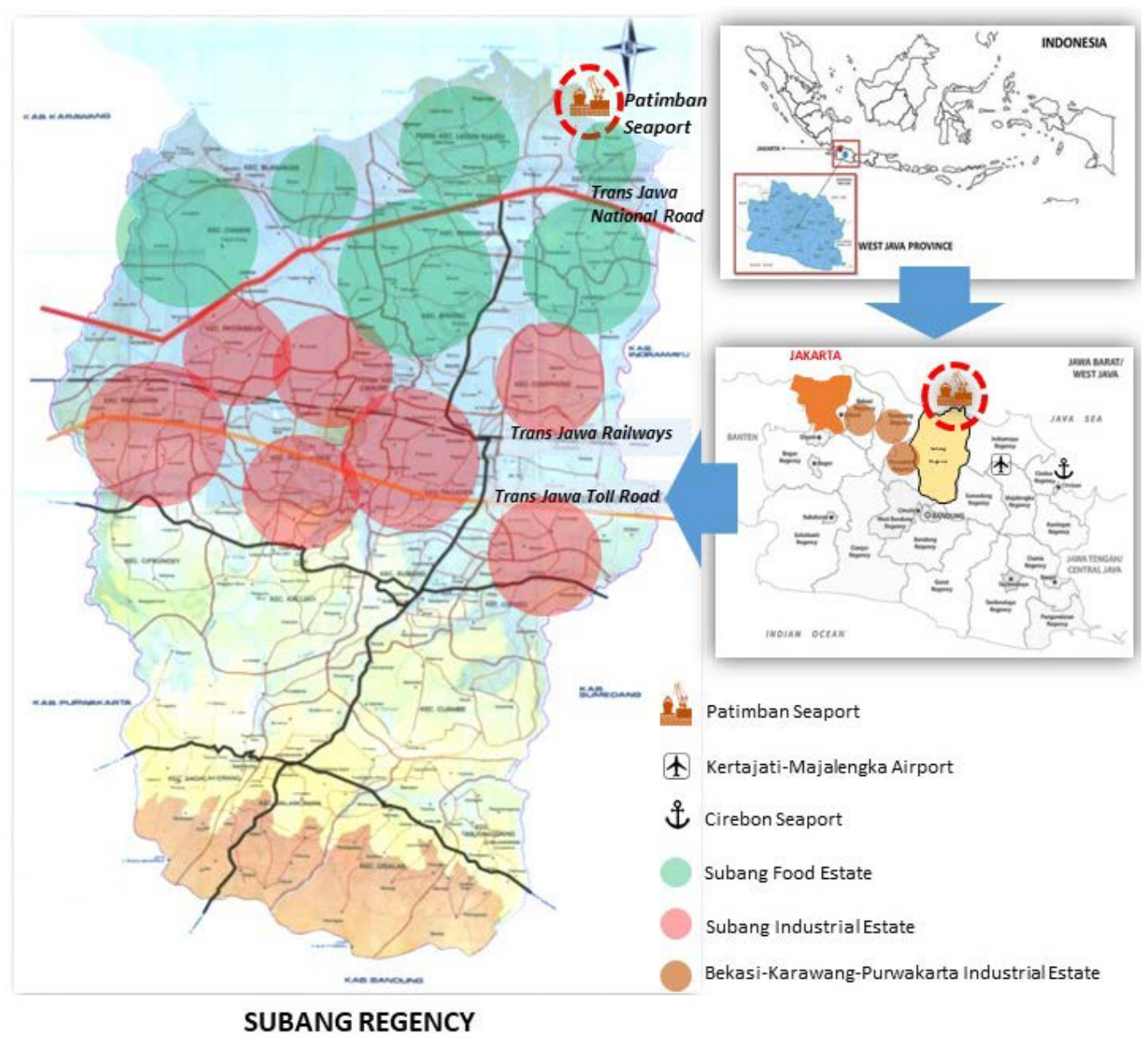

Figure 1. Map of Patimban Seaport. Source: BAPPEDA Subang Regency, modified by authors.

Comprising five regions with three operating container ports, Java as a whole is the island with the highest container traffic in Indonesia [38]. Patimban Seaport, as the fourth container port, has been under construction since 2018 and is intended to reduce congestion at Tanjung Priok Seaport in North Jakarta, which currently accounts for most international trading activities $[38,40,64]$. The Patimban Seaport is located approximately $70 \mathrm{~km}$ from key industrial estates, namely, Bekasi, Karawang and Purwakarta in West Java. In this context, the port project has been confirmed as the National Strategic Project within the Java Economic Corridor Development Plan [40,65]. Patimban Seaport is intended to contribute to the country's Maritime Nation Concept, which strives to strengthen sea connectivity and to expand traffic infrastructure [65].

Regarding land use and potential land competition, it should be noted that Patimban is largely characterised by fisheries and agriculture, while the area has the potential to be developed into a marine touristic area $[40,66]$. Agricultural land and paddy plantations comprise $43 \%$ of Patimban Village [65], and agricultural production is largely shaped by small-scale farming [67]. In the northern area of Subang Regency, the average land plot size accounts for 0.6 ha per household [68]. Subang Regency has been highly important as the third largest area for rice production over recent decades and thus contributes to national food security [63]. In this context, extensive irrigation systems have been developed, and approximately $83 \%$ of paddy rice fields depend on irrigation systems [68].

Examining a spatiotemporal series of satellite images based on MODIS EVI datasets, Figure 2 reveals substantial land use changes between 2016, 2018 and 2019. While paddy fields, fish ponds and plantations prevailed in 2016, later datasets show a massive expansion in savanna. 


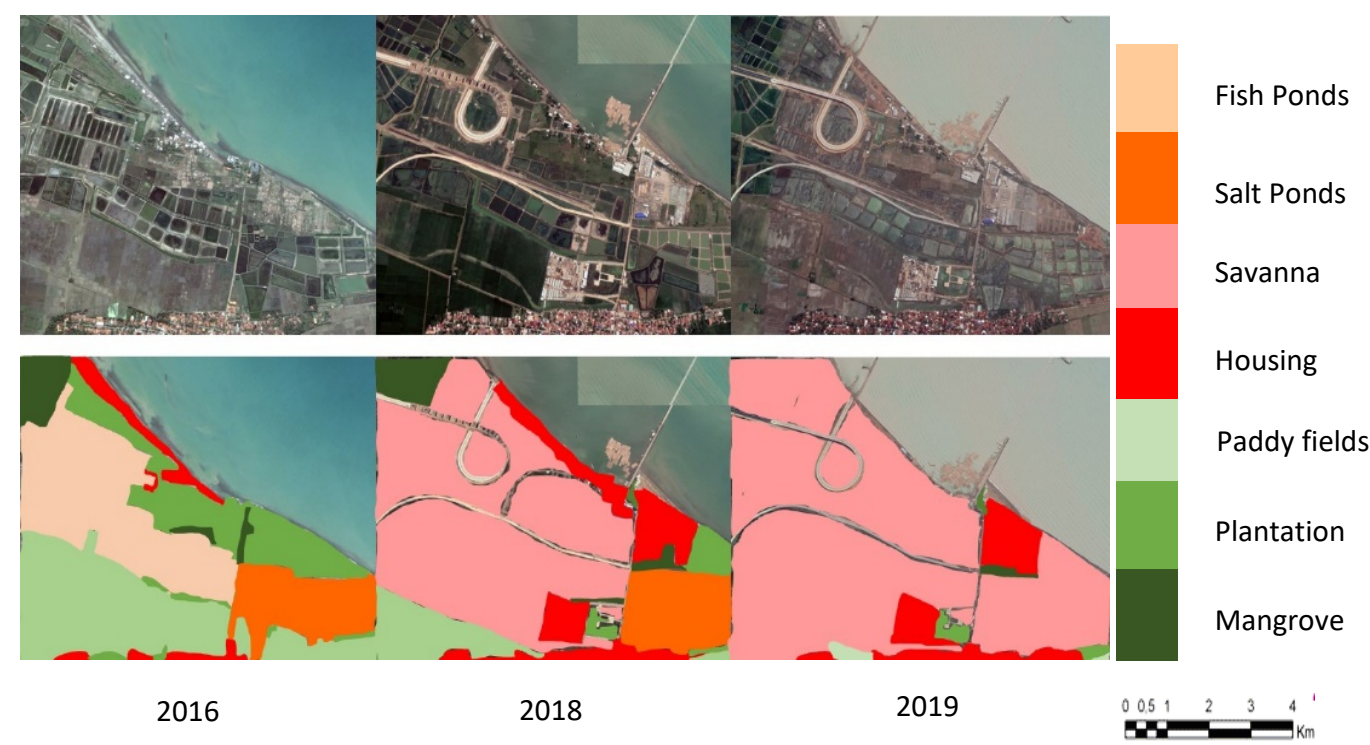

Figure 2. Land Use Changes in Patimban Area. Source: GIS analysis.

By retracing the project development process of Patimban Seaport, three main stages of progress are evident (see Figure 3): (1) the planning stage, (2) the stage of land acquisition and conversion, and (3) the stage of construction.

\begin{tabular}{|c|c|c|c|c|c|}
\hline \multicolumn{2}{|c|}{ Planning Stage } & \multicolumn{2}{|c|}{$\begin{array}{l}\text { Land Market Activities } \\
\text { Land Acquisition and Compensation }\end{array}$} & \multicolumn{2}{|c|}{ Construction Works } \\
\hline 2014 & 2015 & 2016 & 2017 & 2018 & 2019 \\
\hline $\begin{array}{l}\text { Feasibility Study: } \\
\text { Cilamaya or Patimban? }\end{array}$ & $\begin{array}{l}\text { Result of } \\
\text { Feasibility Study: } \\
\text { Patimban is selected as } \\
\text { seaport location } \\
\text { Revised National Spatial } \\
\text { Plan (RTRWN) }\end{array}$ & $\begin{array}{l}\text { Presidential Decree } \\
47 / 2016 \\
\text { Patimban as the National } \\
\text { Strategic Project }\end{array}$ & $\begin{array}{l}\text { New Master Plan of } \\
\text { Patimban }\end{array}$ & $\begin{array}{l}\text { First Stage Development } \\
\text { Inauguration } \\
\text { Access Road Development }\end{array}$ & $\begin{array}{l}\text { Revision: } \\
\text { Provincial Spatial Plan } \\
\text { (RTRWP) } \\
\text { Municipal Spatial Plan } \\
\text { (RTRWK) }\end{array}$ \\
\hline
\end{tabular}

Figure 3. Project Timeline (own representation).

An initial feasibility study for a new seaport project in 2014 marked the beginning of the first stage. The study was conducted by the Japan International Cooperation Agency (JICA) and was not originally set in Patimban but in Cilamaya in Karawang Regency $[69,70]$. Supported by an alternative feasibility study, the designated seaport location was changed to Patimban in 2015 through the revision of the National Spatial Plan (RTRWN) by the central government [69,71]. Anticipating the potential for port expansion [72], the Municipal Spatial Plan (RTRWK) was revised as early as 2014 to include a feeder pier, where previous land use in Patimban was only designated for agriculture, fisheries, tourism and conservation efforts [66]. In 2016, Presidential Decree no. 47/2016 declared the Patimban Seaport to be a National Strategic Project [64,73]. The legal basis provided by the central government marked the beginning of land market activities in Patimban and thus heralded the second stage of land acquisition and conversion [74]. Those activities are still ongoing. In late 2016, the update of the Master Plan of Patimban Seaport designated the specific seaport areas and now serves as the main executive framework for project implementation [64]. It was conducted by national-level actors. In 2018, construction works started, which are planned to be completed by 2024 [75]. As late as 2019, the regional government of West Java adjusted its land use plan in accordance with the municipal and national land use plans and incorporated the Patimban Seaport in the West Java Mid-Term Development Plan $[69,76]$. During the long ratification process of the new plan, the old 
West Java Medium Term Development Plan for 2009-2014, which designates Cilamaya as a seaport location, de facto remained in force [77].

\section{Materials and Methods}

Qualitative interviews and questionnaires served as the main data source for this study [78-80]. Respondents represent actor groups across all spatial levels relevant to the case study context, namely, local (village), municipal, provincial, and national actors (see Table 1), with specific tasks in the project. They represent (1) governmental actors from public agencies across all levels, (2) university experts, (3) NGOs, and (4) local community members, such as landowners, farmers, cultivators, fishermen and other residents.

Table 1. Overview of Respondents (own representation).

\begin{tabular}{|c|c|c|c|c|c|c|}
\hline $\begin{array}{c}\text { Group of } \\
\text { Actors }\end{array}$ & Respondents & Local & Municipal & Provincial & National & TOTAL \\
\hline $\begin{array}{l}\text { Governmental } \\
\text { Sectors }\end{array}$ & $\begin{array}{c}\text { Government of Patimban Village } \\
\text { West Java Development Planning Board } \\
\text { West Java Transportation Board } \\
\text { Subang Development Planning Board } \\
\text { Ministry of Transportation }\end{array}$ & 1 & $\begin{array}{l}1 \\
1\end{array}$ & 1 & 1 & 5 \\
\hline $\begin{array}{l}\text { University } \\
\text { Experts }\end{array}$ & $\begin{array}{c}\text { Subang University } \\
\text { Bandung Institute of Technology }\end{array}$ & & 1 & & 1 & 2 \\
\hline Local People & $\begin{array}{c}\text { Farmers/Land Owners } \\
\text { Cultivators } \\
\text { Fishermen } \\
\text { Others }\end{array}$ & $\begin{array}{c}8 \\
11 \\
5 \\
14\end{array}$ & & & & 38 \\
\hline \multirow[t]{2}{*}{ NGOs } & NGO & 1 & 1 & & & 2 \\
\hline & TOTAL & 39 & 4 & 2 & 2 & 47 \\
\hline
\end{tabular}

Semi-structured interviews (see detail questions in Annex [81]) were conducted with all respondents. Guiding questions addressed all topics in the context of the seaport project: (1) actors and governance processes; (2) land tenure, land ownership and land market; (3) land use conflicts and solutions, land use changes and infrastructure development; and (4) facts, figures and personal opinions regarding current and future developments of Patimban.

Due to organisational issues, interviews with landowners, land cultivators, farmers and fishermen were held in four groups, with each assembled group including only the respective group actors. Through qualitative interviews, we collected data (1) from experts and practitioners, which provides insights into the process and its intentions, and (2) from actors involved in and affected by the project, which reflects respondents' subjective realities, their experiences and understandings of the situation, and how they navigate them all [80]. Additionally, all 39 respondents operating at the local level received a questionnaire with both open and closed questions. With the questionnaires, we collected data reflecting the real-life conditions of actors living and operating on-site in the project setting. Thus, these questions address (1) household information, (2) socioeconomic conditions, and (3) involvement in the project process.

Complementing actor-centred qualitative interviews, we analysed key public documents relevant to the seaport project. The analysed documents constitute the official and public frame for project implementation and comprise the Japan International Cooperation Agency (JICA) Feasibility Study of 2015, the National Spatial Plan (RTRW Nasional) of 2015, the Regional Spatial Plans (RTRW Provinsi Jawa Barat) of 2010 and 2019, the Municipal Spatial Plans (RTRW Kabupaten Subang) of 2014 and 2019, and the Master Plan of Patimban of 2016 (see Table 2). 
Table 2. Materials and Methods.

\begin{tabular}{|c|c|}
\hline Methods & Subjects of Materials \\
\hline Semi-structured interviews & $\begin{array}{ll}\text { - } & \text { Project governance and decision-making } \\
\text { - } & \text { Participation } \\
\text { - } & \text { Land use planning } \\
\text { - } & \text { Land tenure } \\
\text { - } & \text { Land use conflicts }\end{array}$ \\
\hline Survey & $\begin{array}{l}\text { - Actual conditions of land use in inland area and coast line } \\
\text { - } \quad \text { Project construction and supporting activities }\end{array}$ \\
\hline GIS analysis & - $\quad$ Spatiotemporal series of satellite images 2016-2018-2019 \\
\hline Public document analysis & $\begin{array}{ll}\text { - } & \text { Feasibility Study of 2015, Japan International Cooperation } \\
& \text { Agency (JICA) } \\
\text { - } & \text { National Spatial Plan (RTRW Nasional) Year } 2015 \\
\text { - } & \text { Regional Spatial Plans (RTRW Provinsi Jawa Barat) Year } \\
& 2010 \text { and } 2019 \\
\text { - } & \text { Municipal Spatial Plans (RTRW Kabupaten Subang) Year } \\
& 2014 \text { and } 2019 \\
\text { - } & \text { Master Plan of Patimban Year } 2016\end{array}$ \\
\hline
\end{tabular}

We address the research questions first by collating and reflecting our empirical findings on the Patimban Seaport project process with formal Indonesian infrastructure project requirements and procedures representing an analytical framework for this study (see Figure 4). In a second step, we collate and reflect aspects of project governance and decision-making, participation, land use planning, land tenure, and emerging land use conflicts with this framework of formal requirements

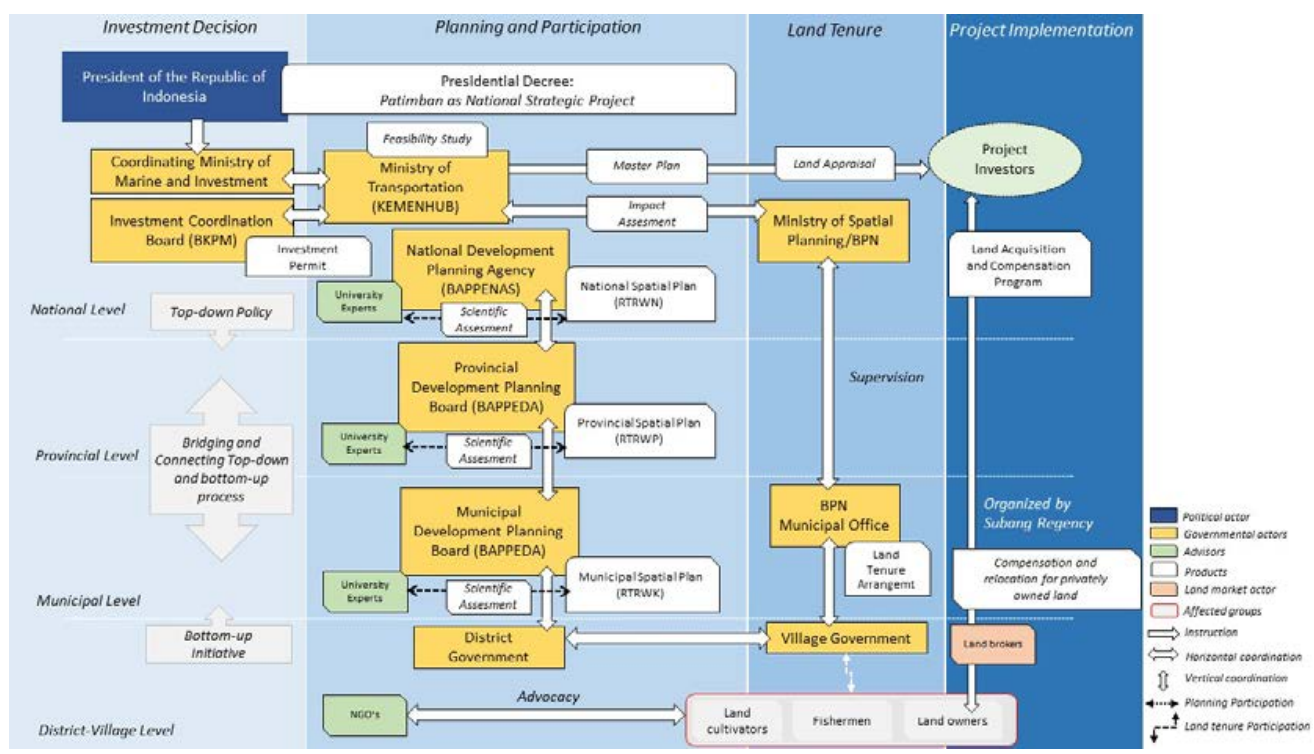

Figure 4. Formal Requirements for Infrastructural Projects (own representation).

Analytical Framework of Formal Requirements for Infrastructural Projects in Indonesia

Although many large-scale infrastructure project decisions emerge at the national level - spearheaded by the President of the Republic of Indonesia and affiliated agencies and ministries, such as the Coordinating Ministry for Maritime and Investment coordinating foreign investment, the Indonesian Investment Coordinating Board (BKPM), the Ministry of Transportation (Kemenhub), the Ministry of Spatial Planning (Kementerian Tata Ruang/BPN), and the National Development Planning Agency (BAPPENAS) - with 
the enactment of regional autonomy in Indonesia in 2000, major and ultimate investment decision-making at the regional scale formally lies in the hands of the affected lower-level governments, such as the provincial and municipal levels [82]. According to the Indonesian investment law and in the context of the decentralisation process of public administration, infrastructure projects at a regional scale must nonetheless be compatible with and consistent with spatial planning across all administrative levels [83,84]. Land use plans, therefore, are ascribed a central role in determining future directions of investment, i.e., regarding location and building permits, permits for groundwater use and other environmental regulations $[69,85,86]$.

As soon as infrastructural project plans take shape, the group of relevant national ministries along with the regional and municipal levels are required to conduct a preliminary impact assessment. Emerging from this, a Presidential Decree declaring jointly agreed upon goals serves as a legal framework for lower-level governments to initiate and conduct scientific impact assessments to design an appropriate land use that matches actual conditions on the ground and future scenarios; they ultimately revise national, regional, municipal, and detailed spatial plans at the village level to consistently align all actors to one vision.

Participation across all administrative levels and including the public along all stages of project realisation is a mandatory component of public planning and decision-making processes in Indonesia. It is stipulated in the National Development Planning System [87], the Spatial Planning Guideline [84], and the Ministerial Decree 24/2007 on Building and Development [86]. It requires opening the process to lower-level governments once a project decision begins to emerge at the central level [74]. In this way, on-the-ground conditions, including anticipated conflicts, should be acknowledged throughout the project process [88]. Once all technical and political aspects have been settled from an administrative perspective, the regional administration in its implementation responsibility is expected to open the process for university experts, NGOs, and other parties of interest, such as research centres or the local chamber of commerce and trade, to ensure a scientific socio-cultural and economic impact assessment [74]. On the municipal level, affected actors, such as potential investors, citizens, and land tenants, are expected to be involved early to convey their livelihood-specific interests, annotations, problems, and solutions through a formal process coordinated by the mayor [88]. All issues, suggestions and recommendations that are proposed to the committee are to be considered in the spatial ratification process at the municipal development planning board (BAPPEDA).

Lower governmental actors are mainly responsible for process implementation and monitoring. They are obliged to provide access to detailed and specific information, options for participation and public hearings at an early stage of planning to comply with norms of governmental accountability [89]. Regional-level actors involve the West Java Government, spearheaded by the Governor of West Java Province and supported by regional boards, such as the Regional Development Planning Board (BAPPEDA). Municipal-level actors comprise the Government of Subang Regency, spearheaded by the Mayor of Subang Regency and supported by several public agencies, such as the Municipal Development Planning Board (BAPPEDA).

In terms of land tenure arrangements, the National Land Agency (BPN) along with consultants and a group of technical boards comprising, i.e., the agricultural board, the coastal and fisheries board, the forestry board, the environmental board, and the housing and settlement board, is required to approach local residents and administrations to collect data on, i.e., land status and tenure arrangements, socioeconomic activities, and the land market to anticipate and prevent potential upcoming land use conflicts. The identification of land tenure arrangements aims to improve public data, particularly land status categorisations, which are later used for acquisition and compensation programmes (see Figure 5). 


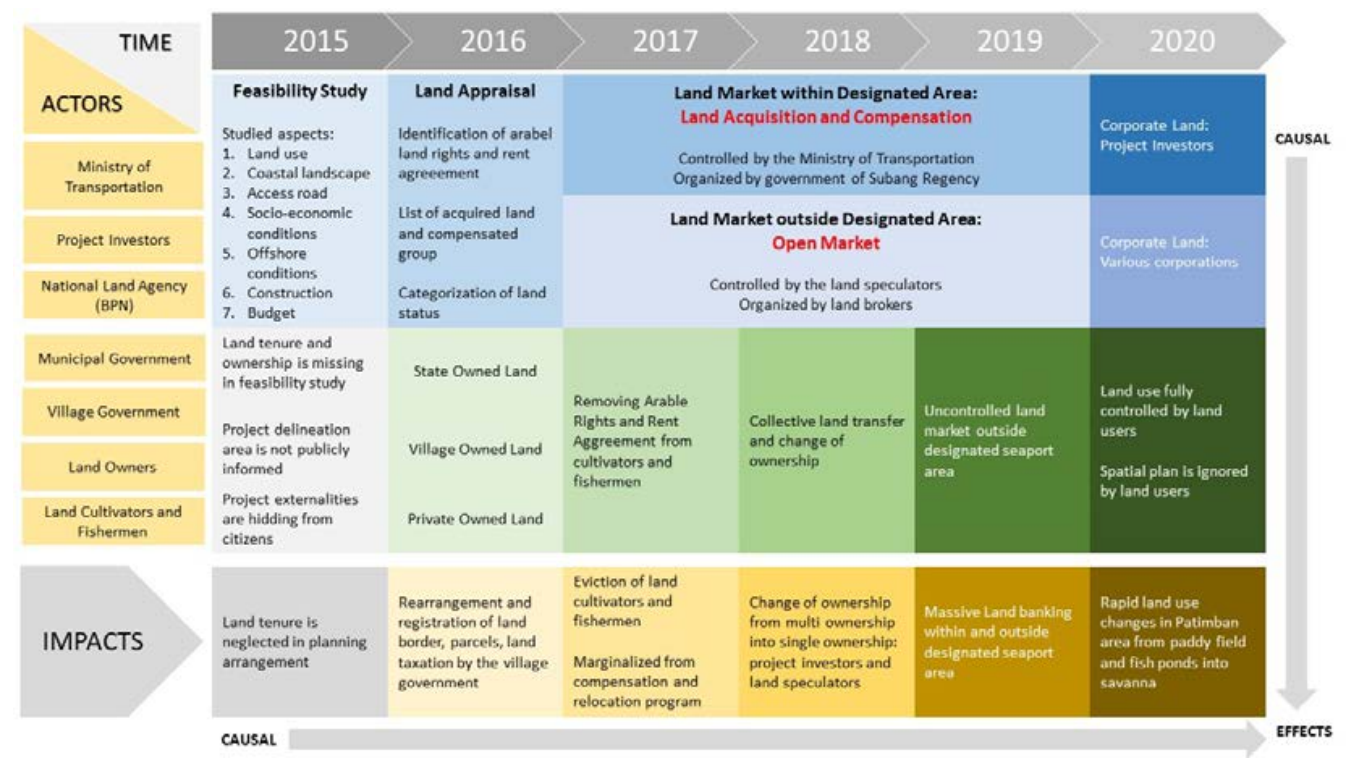

Figure 5. Land Transfer and Impacts (own representation).

\section{Results}

The following results are based on the analysis of documents and interview data. The results outline deviations in major project management processes from formal requirements as well as from the expert recommendations described above and show how these create land use conflicts. They are presented in five steps that highlight (1) the project governance and decision-making process, (2) the participation process, (3) the land use planning process, (4) land tenure, and (5) emerging land use conflicts. The latter provides a synthesis of how the former four analytical units interrelate to create land use conflicts. Table 3 provides an overview of key findings that are subsequently explored in more depth.

Table 3. Key Findings.

\begin{tabular}{|c|c|c|c|}
\hline Sub-Section & Analytical Unit & $\begin{array}{l}\text { Deviation from Formal } \\
\text { Requirements }\end{array}$ & Impacts \\
\hline \multirow[b]{2}{*}{3.1} & \multirow{2}{*}{$\begin{array}{l}\text { Project Governance } \\
\text { and Decision-Making } \\
\text { Process }\end{array}$} & $\begin{array}{l}\text { Hierarchical top-down } \\
\text { decision-making }\end{array}$ & $\begin{array}{l}\text { - National level actors dominate the } \\
\text { decision-making, while lower level actors' } \\
\text { role is reduced to implementation }\end{array}$ \\
\hline & & $\begin{array}{l}\text { On-the-ground operative } \\
\text { decision-making surrendered to } \\
\text { private actors }\end{array}$ & $\begin{array}{l}\text { - No control or anticipation of on-the-ground } \\
\text { project development dynamics } \\
\text { Unintended effects on privileged vs. } \\
\text { marginalised status of specific private } \\
\text { actors groups }\end{array}$ \\
\hline \multirow[b]{2}{*}{3.2} & \multirow[b]{2}{*}{ Participation Process } & $\begin{array}{l}\text { Lacking participation of lower } \\
\text { level administration }\end{array}$ & $\begin{array}{l}\text { Highly limited options to interact with local } \\
\text { stakeholders at an early stage }\end{array}$ \\
\hline & & $\begin{array}{l}\text { Insufficient involvement of local } \\
\text { stakeholders }\end{array}$ & $\begin{array}{l}\text { - } \quad \text { Local interests did not enter the project } \\
\text { process } \\
\text { Privileged vs. marginalised status of } \\
\text { specific local actors groups }\end{array}$ \\
\hline
\end{tabular}


Table 3. Cont.

\begin{tabular}{|c|c|c|c|}
\hline Sub-Section & Analytical Unit & $\begin{array}{l}\text { Deviation from Formal } \\
\text { Requirements }\end{array}$ & Impacts \\
\hline 3.3 & $\begin{array}{l}\text { Land Use Planning } \\
\text { Process }\end{array}$ & $\begin{array}{l}\text { Major inconsistencies of different } \\
\text { level land use plans and actual } \\
\text { land use plan }\end{array}$ & $\begin{array}{l}\text { - Lacking official regulation and legal basis } \\
\text { for project implementation } \\
\text { - Discrepancies regarding designated land } \\
\text { use types }\end{array}$ \\
\hline \multirow{2}{*}{3.4} & \multirow{2}{*}{ Land Tenure } & $\begin{array}{l}\text { Largely informal mechanisms to } \\
\text { establish, transfer and register } \\
\text { land titles and usage rights }\end{array}$ & \multirow{2}{*}{$\begin{array}{l}\text { - Opaque land tenure arrangements } \\
\text { (property rights structures, land plots, land } \\
\text { users, etc.) } \\
\text { Registered land ownership as singular basis } \\
\text { for land users' involvement } \\
\text { Massive shift in land ownership structures } \\
\text { throughout the project process without } \\
\text { proper involvement of land users }\end{array}$} \\
\hline & & $\begin{array}{l}\text { No ex ante land tenure } \\
\text { assessment prior to project } \\
\text { implementation }\end{array}$ & \\
\hline
\end{tabular}

\subsection{Project Governance and Decision-Making Process}

Despite the complex interactive multilevel decision process described above, the Patimban Seaport project has been recognised by various actors as a hierarchical topdown decision-making process $[64,69]$. According to this, at the national level, the project was initiated to develop a new sea hub for transporting manufacturing products from industrial clusters along the corridor of the Jakarta-Cirebon Toll Road [71]. The decision to realise the new project in Patimban was made by the project investor JICA and the central government in accordance with prior feasibility studies [69,70]. By issuing Presidential Decrees, promoting new investment strategies, and revising national spatial plans, the national level set the legal stage for the project and granted it national priority status, thereby confronting the lower-level administration with final project decisions and putting them in a position where they had to await respective legal regulations and negotiate implementation rather than being included in the ultimate project decision-making $[70,73]$.

Thus, overall decision-making power lies in the hands of the national administration. The national legal framework particularly comprises (1) the National Spatial Plan (RTRWN) from 2015 allocating the new seaport to Patimban, (2) Presidential Decrees no. 14/2016 and 47/2016 from 2016 declaring Patimban to be a National Strategic Project, and (3) the Master Plan of Patimban Seaport from 2016 as an executive framework for project implementation scripted by the project investor JICA. The national priority status of the Patimban seaport instructs all public agencies at all levels to support the development of the project and to adjust their land use regulations accordingly [74]. Equally, decisions regarding land acquisition, the designation of specific seaport areas, land prices and compensation mechanisms are negotiated at the national level and directly with the project investor JICA.

Reflecting our interview results, regional-level actors were expected to adapt to this legal stage set by national-level actors by rearranging the Regional Spatial Plan (RTRWP) in accordance with the new seaport project and by supervising the project process [65]. Additionally, municipal-level actors were expected to draft the new Municipal Spatial Plan (RTRWK) and the Detailed Spatial Plan (RDTR) in accordance with their direct superordinate level [67]. The municipal level is responsible for administrative aspects of project implementation. Under the coordination and supervision of the regional administration, the municipal administration commenced scripting the land plotting, land acquisition, and consolidation activities in the respective project area. At the village level, the Government of Patimban Village and its administration were expected to conduct project-relevant on-site activities, such as land registration, land use monitoring, project development supervision, law enforcement, and conflict mediation, under the coordination of the municipal administration [90]. 
In summary, the multilevel interactive decision process changed into a hierarchical top-down mechanism for real decision processes. Formalised planning regulations were side-lined, and decision-making was dominated by central national actors.

However, while public actors at the national level take the lead role in the general decision-making process, our findings indicate that private actors, such as land brokers and land owners, drive the project development dynamics in the direct seaport area with particular regard to land market dynamics. Due to a severe lack of capacity, village level administration has largely surrendered this field of action to private actors, while the remaining affected private actors, such as cultivators, fishermen and other tenants, have little to no influence on project development and decision-making [89]. In this way, project development dynamics caused by those actors could neither be anticipated nor controlled by official planning and decision-making processes.

\subsection{Participation Process}

Our interview results indicate that current participation in the context of Patimban Seaport highly deviates from official regulations. In particular, the negligence of local interests is made evident by the fact that the local public at the village level was not officially involved in or informed about the project and its details until mid-2018 with the start of construction work $[90,91]$. Instead of opening the project process to lower-level administration as soon as project plans emerged, the Village Government of Patimban had no part in technical planning, no negotiation or decision-making power, and no option to interact with its citizens at an early stage due to a lack of information on project plans [91]. Its role was constrained to executive implementation activities only, such as the communication and registration of land designated for seaport use [89].

In this course, a first land acquisition meeting (Musyawarah Pembebasan Lahan) at the village level was initiated in 2015 by the regional government once the seaport project was officially allocated to Patimban. It was conducted by the municipal government of Subang Regency and gathered regional, municipal, and local governmental representatives, the main project developer, community leaders, and local actors affected by the seaport project [90]. Additionally, the municipality of Subang Regency held an investor meeting in 2016 with potential local investors conducted by the Local Chamber of Commerce and Industry (KADIN) to canvass local investment activities aiming at a boost in local economic development in which local economic actors would upscale their capacities and business models by acquiring land in Patimban [67]. The effort to involve local stakeholders was perceived as promising by university experts and NGOs for granting equal rights in a democratised planning process [89].

However, there are two major pitfalls to this approach: (1) First, for reasons of administrative practicability, assembly invitations were issued on the basis of land ownership and registered land use at village-level agencies. Since many land users' property rights are not officially registered, actors, such as cultivators, fishermen, and other informal tenants, remained excluded from information and involvement options [86,87]. (2) The local community participatory process was not anchored to the project planning process but to the land acquisition process only [65,84]. It did not involve project-related decision-making, since formal and legal aspects regarding spatial planning arrangements, specific project areas, land prices, and compensation mechanisms had already been taken at other levels or were negotiated consecutively and in parallel with the project investor as the main decisive private actor at the higher administration level $[64,87]$.

Thus, local stakeholders were not informed of the specific project area designated to the seaport, such that they could not assess whether they would be directly affected or not $[90,91]$.

In contrast to official regulations requiring authorities to provide public access to detailed and valid information to secure accountability and integrity in the decision-making process, the preconstruction project stage can be characterised by opaque information on project purpose, local impacts on livelihoods and environment and compensation schemes 
regarding price mechanisms, resettlements and the relocation of agricultural land to ensure regional food security. In this way, authorities intended to avoid contestation by affected actors and extensive discussions on the land acquisition process [90]. Public hearings are considered time consuming, leading to the deceleration of the overall project process, and governmental bodies aim to meet investors' demands and project goals [74]. Thus, economic interests and project investors' interests are prioritised over local stakeholders' interests [74].

In summary, the participation process reflects the interests of those actors' groups striving to support and speed up the investment process. In this way, local actors lacked sufficient opportunities to convey their interests regarding their property and (future) livelihoods.

\subsection{Land Use Planning Process}

Contrasting with the formal requirements, spatial planning in the context of the Patimban Seaport project has been characterised by major issues with inconsistency according to our interview results. With the revision of the National Spatial Plan (RTRWN) in 2015, the new seaport was allocated to Patimban, with the Masterplan of Patimban constituting the main executive framework for project implementation. However, lower-level processes revising spatial plans accordingly lagged behind the project process. The regional government of West Java Province introduced its new Regional Spatial Plan as late as 2019, when Patimban Seaport was declared part of the West Java mid-term Development Plan [69,76]. This was due to the extensive formal ratification process of the plan, such that the older version of 2010, which designates Cilamaya but not Patimban for potential infrastructural development projects, remained in force until 2019. The necessity of fulfilling formal requirements such as a scientific assessment by university experts and a public hearing with stakeholders as well as an administrative consultation with the Ministry of Home Affairs (Kementerian Dalam Negeri), the Ministry of Spatial Planning (Kementerian Agraria Tata Ruang/BPN), and the National Development Planning Agency (BAPPENAS) delayed the revision of the Regional Spatial Plan [74]. Consequently, seaport project processes were not in accordance with public spatial planning at that time, in particular, contrasting with the Regional Spatial Plan.

Although official regional plans were passed in 2019, the municipal government of Subang Regency had already adjusted the Municipal Spatial Plan (RTRWK) in 2014 to include a feeder pier in the land use plan that was not yet allocated to commercial trade in goods but could serve strategically as a reference and starting point to expand a seaport project, thus supporting the national government's decision to realise the new seaport in Patimban [66,74]. Thus, despite the lack of regional regulations, the municipal government simply adopted the seaport project vision from the national level at an early stage

For the municipal government of Subang Regency but likewise for on-site project implementation processes, such as land acquisition and construction work, this inconsistency between national, regional, and municipal land use plans also meant a lack of official regulation in implementing the seaport project [74]. Thus, and strictly speaking, one could argue that project implementation processes were conducted without full legal justification and legitimacy from higher administrative levels [74], while they also failed to receive legitimacy from bottom-up mechanisms or the involvement of local stakeholders [89].

Apart from inconsistencies regarding project adoption among spatial plans at all administrative levels, there are major discrepancies regarding the designation of land use types, e.g., agricultural, conservational, or commercial zones. While regional and municipal spatial plans still stipulate a prevalence of agricultural and conservational land use types, planning agencies developed large-scale seaport projects without proper reference to existing land use plans $[88,89]$. Thus, we observe a clear discrepancy between on the ground land use and land use changes and official land use plans.

In summary, the interactive multilevel planning process was replaced in favour of an investment-friendly procedure accepting a severe lack of procedural accuracy and comprehensiveness in planning. Various plans contradicted each other and were only 
adapted ex post, such that they did not provide their intended conflict resolution and management function.

\subsection{Land Tenure}

Land tenure in Patimban is characterised by high levels of informality. Land can be village-owned, which largely refers to indigenous land (tanah adat), state-owned, or privately owned [90]. Those lands are often leased to aligned land users holding various usage rights. Most frequently, private land is leased to smallholders for cultivation. Currently, approximately 300 cultivators strongly depend on arable land to feed and sustain their families in the new seaport area of Patimban [88,90].

Formal mechanisms exist to register land status and property rights. In the context of formal land registration and land titling programs, land titles are granted and registered according to land regulations. Apart from public programs, land ownership and usage rights are established in regular land market activities by the means of selling and buying or leasing, which nonetheless stipulates a formal administrative registration procedure.

However, formal mechanisms to establish, transfer, and register land titles and property rights are rarely enacted in practice due to complex bureaucratic procedures. Rather, land transfers and lease contracts-particularly between private actors-are informally agreed upon by mutual agreement without formal registration, making land tenure arrangements nontransparent and creating difficulties with regard to the verification of usage rights and overviews of land plots and users [88,91].

Due to high levels of informality and opacity, an assessment of land tenure, land status, and land markets has not been conducted by respective agencies in the area of Patimban in preparation for the seaport project. The interview results point to time pressures imposed by the project investor, the extensiveness of such a task considering the high number of unregistered usage rights, and a lack of administrative capacity [74]. Instead, registered land ownership constituted the foundation for land users' involvement, and only registered land owners were invited to meetings and taken into account in terms of compensation mechanisms. All informally aligned or unregistered land users thus remained excluded from the formal process [74].

At the same time, land acquisition and land transfers in the context of the seaport project fundamentally altered the local tenure arrangement. In 2013, more than $80 \%$ of landowners in the seaport area were represented by local residents [90]. Land parcels were commonly small and usage was in accordance with the Municipal Spatial Plan (RTRWK) at that time, mainly agriculture and fisheries [66,91]. In the course of project implementation, the project investor JICA acquired 334 ha of productive agricultural land through the official land acquisition and compensation programme as set out by the Ministry of Transportation and organised by Subang Regency [90]. This land was designated in the original Masterplan of Patimban issued in 2016 and announced during the preliminary land acquisition meeting as the seaport area [92]. In this way, numerous small parcels formerly owned by Patimban residents, of which 320 ha were used for paddy rice production and 14 ha of fish and salt ponds, were transferred to the project investor for seaport use $[75,90]$. A local NGO states that by the end of 2015, 67 local landowners as well as 31 cultivators and 4 fishermen aligned to those land plots had lost access to them, accompanied by a loss of usage rights and thus their livelihoods $[88,93,94]$. By the end of 2019, the entire seaport area had been transferred into the singular ownership of the project investor [90,95].

Consequently, official land transfers as part of project implementation led to a shift from individually held land to land held by investors and companies (corporate land) in terms of land status. From an administrative perspective, land transfer resulted in major benefits: project investors were obliged to register the new land status, so the process simplified the ground tenure arrangements, improved the quality of land registration data at the village level, and yielded additional revenues from tax payments [90].

Apart from this, official land transfers also had indirect impacts on private land market activities that were not anticipated by planning agencies. With increasingly dynamic 
drops in land values accompanying official land transfers and increasing information rates reaching the broader public, uncontrolled land market activities beyond designated project area boundaries expanded rapidly, involving local investors, adjacent landowners, and brokers (Figure 5). Attracted by promising future seaport project scenarios and low land prices, local investors from cities around Subang Regency acquired particularly unproductive paddy rice fields and mangrove forests along the shoreline and adjacent to the future seaport with the help of private land brokers [90]. Land brokers, thereby, approached land owners and triggered a chain reaction of land sales [96] — and even those with land plots beyond project area boundaries - to sell their land, proactively anticipating future land use changes and deteriorating land prices and quality $[88,90]$.

In summary, project development led to a massive change in land ownership that could not be controlled by official land tenure regulations and supported by the existing informal elements of land tenure processes.

To visualise and conclude the land tenure processes in the context of Patimban Seaport, Figure 5 provides an overview of the formal land acquisition process, in which land was transferred to project investors, and of a second stage of land transfers with regard to uncontrolled land market activities evolving from changing land market and tenure conditions in the Patimban area. With regard to official land transfers, formal mechanisms exist to register land statuses and property rights in land appraisal programs that have been initiated by the Ministry of Transportation and consultants. In the context of formal land registration and land titling programs, land titles are granted and registered according to land regulations. Within the land appraisal programme, land ownership and land status are established in the Land Acquisition and Relocation Program (LARAP) document [97], which stipulates a formal administrative registration procedure that is organised and supervised by the Subang government.

\subsection{Land Use Conflicts}

The processes described above, which deviate substantially from the nominal formal requirements, do not merely account for problems in themselves but are highly interrelated. They create complex and specific land use conflicts that consequently led to high degrees of local dissatisfaction and project rejection among various groups of actors.

Although planning agencies and related actors pursued preventative strategies to reduce conflicts in Patimban Seaport by design in general, such as the reduction in land competition through the installation of a deep seaport, the designation of alternative agricultural areas, and the promotion of agricultural intensification measures, the risk potential of insufficient transparency and stakeholder involvement was underestimated. Hierarchical top-down decision-making, in which major issues regarding, i.e., the designation of project areas, land acquisition procedures and compensation mechanisms were negotiated at the national level, restricted lower-level administration to executive implementation activities, thereby missing the opportunity to assess local conditions and anticipate future conflicts. This caused one of the major conflicts, which was constituted by discrepancies between national and lower-level planning targets. Conflict issues regarding diverging land uses stipulated in different level land use plans, such as the prevalence of agricultural and conservational land uses versus commercial land uses and housing, had major implications for higher-level issues, such as national food security given Patimban's role in paddy rice production.

Table 4 provides an overview of the land use conflicts observed and by which analytical units they were mostly driven. 
Table 4. Conflicts, Drivers and Impacts.

\begin{tabular}{ccc}
\hline CONFLICTS & DRIVERS & IMPACTS \\
\hline Governance & Spatial plan lagged behind project development & $\begin{array}{c}\text { Legal ambiguity for land use-related } \\
\text { seaport development }\end{array}$ \\
\hline Land tenure/land transfer & Deprives registered land users & $\begin{array}{c}\text { Shifting land ownership and removing land } \\
\text { rights from individual to corporate }\end{array}$ \\
\hline Accessibility & Access road development and closed project area & Limited irrigation and access to the land plots \\
\hline Conservational & Inconsistencies of land use regulation and & Massive development in protected coastal area \\
\hline
\end{tabular}

While national project plans progressed quickly, the revision of spatial plans, particularly the Regional Spatial Plan, lagged behind project development. This led to a state of legal ambiguity: the revised National Spatial Plan as well as Presidential Decrees 14/2016 and 47/2016 declared Patimban to be a National Strategic Project, while the Regional Spatial Plan still in force did not designate Patimban as a potential development area but designated the majority of it for agricultural and conservational use. With regard to quickly progressing project implementation and construction works, a re-adjustment of spatial plans in accordance with the seaport is only logical. However, it retrospectively deprives registered land users of the legal basis to proceed against project plans.

The initiation of many court proceedings against project plans, particularly against land acquisitions, can be traced back to a lack of regulations and regional spatial plans legitimising the seaport project [88] and to the late and insufficient involvement of local stakeholders. Inadequate information, i.e., regarding the specific designation of affected land parcels, led to increased uncertainty and a lack of future prospects among land users, spurring both conflicts over those lands and uncontrolled land market activities even beyond directly affected seaport project areas. Simultaneously, it should be noted that only officially registered land users were involved at all, while major stakeholder groups, such as informally aligned land users, were excluded from participation processes and, as a consequence, from developing alternatives. This, in turn, is largely because land tenure arrangements remain widely opaque to both local administration and project developers due to high levels of informality.

Most specifically, the loss of local livelihoods represents one of the most pressing land use conflicts emerging from land use changes in Patimban, but it accompanies several other factors, such as an alteration of land status, property rights structures and accessibility. Although planning agencies and related actors aimed to reduce land competition between local land users and project investors by installing a deep seaport with an offshore loading dock that intentionally occupied less coastal land through the use of 350 ha of reclaimed land, the onshore seaport area designated for investors' use nonetheless comprises 334 ha of land formerly owned and cultivated by locals.

Generally, land transfers for seaport development led to a shift from individually held land to corporate land in terms of land status [88]. While land parcels in 2013 were commonly small and in the hands of local residents, by the end of 2019, the seaport area belonged to the project investor. Altered property rights structures largely included the privatisation of previously commonly used areas, such that numerous landowners and cultivators lost access and usage rights to those lands [88,90,91].

Conflict abatement strategies, including the relocation of agricultural production with the designation of alternative cultivation areas and the provision of transportation infrastructure, were considered inadequate by respective stakeholders-not least because abatement strategies and compensation schemes neither involved nor considered the particular interests of land users [90]. The proposed agricultural intensification measures and the designation of agricultural land approximately $25 \mathrm{~km}$ outside Patimban village utilising savanna and abandoned fields failed to recognise local cultivators' opportunities and capacities with regard to distance and higher production costs due to the lack of 
infrastructure $[88,89,91,98]$. The extensive and central seaport area disrupted regional irrigation infrastructures and daily commutes alike [90]. Former regional irrigation systems providing more than $80 \%$ of paddy rice fields with irrigation water lost efficiency with the decrease and scattering of agricultural land dependent on irrigation [63,68]. Farmers and residents with remote land plots beyond the seaport area were forced to detour around the central project area to reach their land plots [99]. Similarly, the provision of water pumps and a newly constructed ring road provided by the village government and the developer falls short because the new facilities do not directly connect settlements and agricultural plantations but mainly serve project-related uses.

Apart from a reduction in agricultural land and thus a loss of local livelihoods, the seaport project, including conflict abatement strategies, was unable to prevent conservational conflicts, which largely derived from discrepancies between national and local land use planning targets. Although the Municipal Development Planning Board had established a major conservation area focusing on the protection of agricultural land and fisheries on the coastline of Patimban $[67,68]$, the national government located the seaport area on the north coast of Patimban in accordance with investors' location preferences [88]. Regarding conservational efforts, the offshore reclamation area had large negative impacts on the coastal green belt and coastal ecosystems of mangroves [89]. Additionally, supporting facilities, such as access roads and construction activities, disrupted coastal ecosystems. The installation of breakwater walls along the coastline, especially in areas adjacent to fish ponds, was carried out as a solution to protect inland areas from sea water abrasion, but this effort is seen as environmentally unfriendly by local environmentalists due to its extensive use of natural stones needed for the installation of breakwater walls [88]. Instead, environmental experts suggest planting and preserving mangrove vegetation along the coastline to prevent erosion. Apart from representing buffer zones, mangroves could create new habitats for sea life, providing income opportunities for local fishermen.

In summary, and returning to von der Dunk et al.'s [33] definition, land use conflicts in Patimban emerged mainly among the local landowners, cultivators and aligned tenants on the one hand and proponents of the seaport project including governmental actors and actors in the planning process, investors, and brokers on the other hand. Additionally, environmental actors generally opposed project plans. Conflict-afflicted land units naturally comprised areas designated for seaport use that largely represented agricultural land. However, construction activities have also had negative effects on Patimban's wider coastline with regard to disrupted maritime and coastal ecosystems. Thus, conflict issues mainly comprised conservational issues and issues of accessibility as well as a tremendous reduction in usage rights for local residents accompanying a radical change in rural livelihood opportunities in the area. In addition to those conflicts on the ground, land use conflicts emerged in accordance with Kaswamila and Songorwa's [34] definition from the planning and governance process, which was characterised by major inconsistencies and discrepancies, particularly with regard to different administrative levels and their land use plans.

\section{Discussion}

Overall and with regard to the multitude of conflict parties and actors, it can be stated that local landowners and aligned tenants faced the most direct negative impacts from project consequences, since this group lost property rights and access to land and thus their livelihoods. Land use conflicts emerged from and were spurred by three major sources: (1) inconsistent and incompatible land use plans and governance processes, (2) a lack of stakeholder participation, and (3) insufficient land tenure arrangements. Several of these factors have been individually outlined as posing frequent problems in megaproject governance processes in the global south by researchers [12,15,17-20]. Although they are more or less well known, we must state the same problems again. This case study, however, exemplifies additionally, in a specific and comprehensive context, how those three factors are interrelated and interact in their potential to spur land use conflicts. 
It is largely undisputed that infrastructural development, particularly the development of port infrastructure in maritime nations, provides highly promising opportunities for country development $[15,38,40]$. Felsenstein et al. [5] comprehensively argue that infrastructure development in congested coastal areas naturally occurs at the expense of other land uses. However, infrastructural mega projects have the potential to spur major land use conflicts if available land is not managed efficiently by balancing development, costs and benefits across many competing stakeholder groups [5]. The Patimban Seaport project is exemplary in showing how mismanagement and inadequate planning processes lead to market failure, land abandonment and dereliction and how it overly burdens local communities with costs $[5,17,19,36]$, thus leading to project rejection in those stakeholder groups and land use conflicts [11,21-23]. The following sections will explain these effects in more detail.

(1) First, inconsistent and incompatible land use and project planning processes contrast official regulations stipulating consistency and decision-making power across all administrative levels to ensure a planning process characterised by integrity with regard to maintaining and protecting principles of democracy and regional autonomy. In Patimban, project plans were developed, decided upon, and implemented in a top-down process on the national level in cooperation with project investors and overriding the lower-level administration. Project promoters, including central governmental actors and project investors, acted as primary stakeholders and exercised the main decision-making power with regard to maximising internal project benefits [5,46]. Land use planning-as an official legal basis for project implementation-lags behind actual project processes. Exemplary of this is the long ratification process for the adjusted Regional Land Use Plan, while construction works in Patimban had already started creating facts on the ground. In this way, the specific value of formal planning procedures in providing long-term control of land development and anticipating potential land use conflicts did not come into effect. In contrast, a retrospective adjustment in favour of the seaport project damaged land users rights and spurred uncertainties and conflicts $[17,19]$.

(2) Many of these inconsistencies emerged due to a twofold lack of stakeholder participation: a) a lack of lower-level administration involvement and b) a lack of local community involvement. In particular, a lack of lower-level administration involvement counteracts and undermines the integrity of still-fragile democratic and constitutional regulation and legislation in the context of Indonesia's decentralisation efforts. The extensive ratification process of the Regional Spatial Plan, including an impact assessment by experts and public hearings, seems wholly unrelated to the progressing land acquisition and construction activities in the seaport area. As assessments of actual on-the-ground situations were not entering the project decision-making process, problems and potential conflicts could not be properly anticipated by project developers. Instead, lower-level administration was occupied with project implementation tasks and responsibilities exceeding their capacities.

Late and superficial local stakeholder involvement also failed to increase the democratic legitimacy of the project. Delayed and incomplete information created uncertainties amongst potentially affected actors, leading to further uncontrolled and unanticipated excessive land market activities. Moreover, with the involvement of stakeholders based on registered land ownership only, informally aligned land users were excluded and thus marginalised in the context of the seaport project. It became evident that local communities in Patimban represented merely secondary stakeholders and held little to no decisionmaking power $[21,47,48]$, although they directly suffered environmental degradation and a loss of livelihood $[5,21,22,46]$.

(3) Inadequate identification, and thus the marginalisation, of relevant stakeholder groups largely originated from inadequate tenure arrangements. Project governance and planning also relied on existing public data made available from public administration, including registered land ownership data as the basis for stakeholder involvement, thus privileging land status [20]. Public administration was thus held accountable for land tenure data. However, lower-level administration in Indonesia frequently has no capacity to 
account for and assess tenure arrangements in the short run, particularly since Indonesian land tenure and land management systems comprise a highly pluralistic and fragmented legal system [53-55]. Thus, the official but incomplete data basis of registered land users is demonstrated, thereby—knowingly or unknowingly—neglecting actual highly diverging tenure arrangements frequently characterised by high informality, which puts local communities in a weak position in terms of their capacity to enforce their rights $[17,20]$. That a mere formalisation of tenure arrangements through land registration and land titling frequently succeeds in achieving administrative benefits but fails due to a process of upward filtration was also evident in Patimban: numerous land users lost access and usage rights over land they were informally aligned to by an official transfer into the registered singular ownership of the project investor $[18,19,53,57,58]$.

Given the arguments above, it becomes evident that Indonesia does not primarily lack formal requirements to ensure a democratic and balanced planning and governance process for infrastructural mega projects, but the lower-level administration did lack adequate and strong monitoring, controlling and enforcement mechanisms, its capacity to intervene was not consolidated and it was not included as a primary stakeholder with the central governmental actors. Moreover, land tenure arrangements needed to be revealed-not in the short run-up to the megaproject but comprehensively across all regions to provide project developers with adequate information and thereby proactively depriving them of the chance to intentionally exclude all stakeholder interests; this would further ensure that local communities could speak up as primary stakeholders in a strong position of rights enforcement. Only if rights, law enforcement and a proper monitoring process by independent and strong actors are ensured can stakeholder participation unfold its potential to shape governance processes in a democratic way.

In terms of the implications for policy, research on adequate mechanisms and options for law enforcement, the empowerment of actors and the tenure security for informally aligned and marginalised groups need to be intensified, since currently available options for formal registration processes have major disadvantages and have yet been unable to generally strengthen the position of informally aligned tenants.

The important recommendations for the further development of the Indonesian regulatory system are embedded in international debates about the analysis and further development of spatial planning approaches. First and foremost, authors call for more complex analysis of interrelated governance activities [100] and a better understanding of formal and informal governance modes [101], including the explicit role of power relations in planning processes [102]. The results explicitly show the importance of local knowledge in planning processes $[102,103]$ and the important role of knowledge holders and space holders [104]. As a consequence, new modes of governance away from hierarchical control towards more interactive governance $[105,106]$ are seen as adequate in mega projects.

\section{Conclusions}

This article investigated the research question of how mega project governance, land use planning, and actual land use interact by analysing the case of Patimban Seaport, Indonesia. We observed that land use conflicts emerged from three major sources: (1) inconsistent and incompatible land use plans and governance processes, (2) a lack of stakeholder participation, and (3) neglected land tenure arrangements, and that all three sources are highly interrelated. Formal requirements for mega project governance ensuring a transparent and democratic planning process were, in various cases, ignored in favour of time- and cost-efficient project development. Therefore, project governance and planning processes occurred ahead of effective public administrative land management and official land use planning adjustments, leading to major inconsistencies between actual land use on the ground and land use stipulated by spatial plans.

Within this disintegrative and parallel procedure of public land use planning and central and investor-driven project governance, it becomes evident that lower-level public actors' and local stakeholders' interests are quite often neglected, and participatory ap- 
proaches were reduced to a minimum. Local communities were not adequately involved because participatory approaches relied on stakeholder identification based on registered land ownership such that informally aligned tenants were excluded given that actual tenure arrangements remained officially opaque to both project governance representatives and public administration. In this context, we furthermore observed that local landowners and aligned tenants suffered most and directly from project consequences because this group found itself in a particularly weak position with regard to their rights enforcement capacity.

Our results imply that formal requirements to ensure project processes of integrity were not lacking, but effective monitoring, control and law enforcement mechanisms were needed. Moreover, a comprehensive public revelation of actual tenure arrangements would allow for better tenure-responsive land use planning that includes informally aligned tenants to design governance processes to maintain accountability for socioeconomic, socioecologic, and political compatibility.

The results developed within this case study follow the recommendations made for land system science, following a high integrative complexity of thematic interactions (actors, planning, land tenure, conflicts) [100]. From the authors' perspective, this is a way to substantiate complex nexus structures in a "bottom up" way. The case study shows in an exemplary way the interrelations and trade-offs in foreign direct investments (FDIs) of this magnitude, which are also reflected more generally in the telecoupling approach $[107,108]$. As demanded by the research community [101], the specific impacts of a nationally desired FDI are analysed here as an example. Viewing governance debates, the recommendations show ways towards co-design approaches of multilevel policy $[105,106]$.

Author Contributions: Conceptualisation, formal analysis, investigation, resources, writing-original draft preparation, visualisation, R.S.; investigation, resources, A.M.G. and T.W.; conceptualisation, supervision, writing-review and editing, A.M.G. and T.W. All authors have read and agreed to the published version of the manuscript.

Funding: This research received no external funding.

Data Availability Statement: The interview data presented in this study are available on request from the corresponding author. The data are not publicly available due to privacy.

Acknowledgments: The authors would like to thank the Ministry of Transportation of the Republic of Indonesia, Regional Development Planning Board of West Java Province, Regional Development Planning Board of Subang Regency, People of Patimban Village, Pusakanagara District of Subang Regency for providing valuable information for this research.

Conflicts of Interest: The authors declare no conflict of interest.

\section{References}

1. WBGU. Available online: https://www.wbgu.de/de/publikationen/publikation/landwende (accessed on 10 February 2021).

2. United Nations. Available online: http://www.un.org/sustainabledevelopment/development-agenda (accessed on 23 September 2020).

3. De Groot, R. Function-analysis and valuation as a tool to assess land use conflicts in planning for sustainable, multi-functional landscapes. Landsc. Urban Plan. 2006, 75, 175-186. [CrossRef]

4. Felsenstein, D.; Lichter, M. Land Use Change and Management of Coastal Areas: Retrospect and Prospect. Ocean. Coast. Manag. 2014, 101, 123-125. [CrossRef]

5. Felsenstein, D.; Lichter, M.; Ashbel, E. Coastal Congestion: Simulating Port Expansion and Land Use Change under Zero-Sum Conditions. Ocean. Coast. Manag. 2014, 101, 89-101. [CrossRef]

6. Small, C.; Nicholls, R.J. A Global Analysis of Human Settlement in Coastal Zones. J. Coast. Res. 2003, 19, 584-599.

7. Czermański, E.; Oniszczuk-Jastrząbek, A.; Zaucha, J.; Pawłowska, B.; Matczak, M.; Szydłowski, Ł. Preconditions of new container terminal location in the Maritime Spatial Planning framework. A case study for the Central Port Concept in Gdańsk. Mar. Policy 2021, 130, 104585. [CrossRef]

8. Ehler, C.; Zaucha, J.; Gee, K. Maritime/Marine Spatial Planning at the Interface of Research and Practice. In Maritime Spatial Planning; Zaucha, J., Gee, K., Eds.; Springer International Publishing: Berlin, Germany, 2019; pp. 1-21.

9. McGrath, K. The Feasibility of Using Zoning to Reduce Conflicts in the Exclusive Economic Zone. Buffalo Environ. Law J. 2004, 11, 183-194.

10. Zaucha, J.; Gee, K. Maritime Spatial Planning: Past, Present, Future; Springer International Publishing: Berlin, Germany, 2019. 
11. Delphine; Witte, P.; Spit, T. Megaprojects-An Anatomy of Perception. DisP Plan. Rev. 2019, 55, 63-77. [CrossRef]

12. Firman, T. Urban Development in Indonesia, 1990-2001: From the Boom to the Early Reform Era through the Crisis. Habitat Int. 2002, 26, 229-249. [CrossRef]

13. Ducruet, C. Port Regions and Globalization. In Ports in Proximity: Competition and Coordination among Adjacent Seaports; Notteboom, T.E., Ducruet, C., de Langen, P., Eds.; 2016; pp. 67-80.

14. Brotosusilo, A. Littoral and Coastal Management in Supporting Maritime Security for Realizing Indonesia as World Maritime Axis. In Proceedings of the IOP Conference Series: Earth and Environmental Science 30 3rd International Conference on Geological, Geographical, Aerospace and Earth Science 2015 (AeroEarth 2015), Jakarta, Indonesia, 26-27 September 2015; Volume 30, p. 011001.

15. Dahuri, R.; Dutton, I.M. Integrated Coastal and Marine Management Enters a New Era in Indonesia. Available online: https:/ / www.researchgate.net/profile/Ian_Dutton/publication/237600429_Integrated_Coastal_and_Marine_Management_ Enters_a_New_Era_in_Indonesia/links/5786f22508aef321de2c7288/Integrated-Coastal-and-Marine-Management-Enters-aNew-Era-in-Indonesia.pdf (accessed on 12 August 2020).

16. Rochwulaningsih, Y.; Sulistiyono, S.T.; Masruroh, N.N.; Maulany, N.N. Marine Policy Basis of Indonesia as a Maritime State: The Importance of Integrated Economy. Mar. Policy 2019, 108, 103602. [CrossRef]

17. Dhiaulhaq, A.; McCarthy, J.F.; Yasmi, Y. Resolving Industrial Plantation Conflicts in Indonesia: Can Mediation Deliver? For. Policy Econ. 2018, 91, 64-72. [CrossRef]

18. Firman, T. Major Issues in Indonesia's Urban Land Development. Land Use Policy 2004, 21, 347-355. [CrossRef]

19. Hudalah, D.; Winarso, H.; Woltjer, J. Gentrifying the Peri-Urban: Land Use Conflicts and Institutional Dynamics at the Frontier of an indonesian Metropolis. Urban Stud. 2016, 53, 593-608. [CrossRef]

20. Deininger, K.; Selod, H.; Burns, A. The Land Governance Assessment Framework: Identifying and Monitoring Good Practice in the Land Sector. Agriculture and Rural Development. World Bank, 2012. Available online: https: / openknowledge.worldbank. org/handle/10986/2376 (accessed on 3 July 2020).

21. Delphine; Busquet, M.; Santpoort, R.; Witte, P.; Spit, T. Living on the Edge: Identifying Challenges of Port Expansion for Local Communities in Developing Countries, the Case of Jakarta, Indonesia. Ocean. Coast. Manag. 2019, 171, 119-130. [CrossRef]

22. Delphine; Witte, P.; Spit, T. Bridging the Perception Gap? When top-down built megaprojects meet bottom up perceptions: A case study of Suramadu Bridge, Indonesia. Asian Geogr. 2020, 163, 1-23. [CrossRef]

23. Barron, P.; Diprose, R.; Woolcock, M. Local Conflict and Development Projects in Indonesia: Part of the Problem or Part of the Solution. World Bank Policy Res. Work. Pap. 2007, 4212, 14-29.

24. Di Maddaloni, F.; Davis, K. The Influence of Local Community Stakeholders in Megaprojects: Rethinking their Inclusiveness to Improve Project Performance. Int. J. Proj. Manag. 2017, 35, 1537-1556. [CrossRef]

25. Chen, S.; Pearson, S.; Wang, X.H.; Ma, Y. Public Participation in Coastal Development Applications: A Comparison between Australia and China. Ocean. Coast. Manag. 2017, 136, 19-28. [CrossRef]

26. Dhiaulhaq, A.; de Bruyn, T.; Gritten, D. The Use and Effectiveness of Mediation in Forest and Land Conflict Transformation in Southeast Asia: Case Studies from Cambodia, Indonesia and Thailand. Environ. Sci. Policy 2015, 45, 132-145. [CrossRef]

27. Chigbu, U.E.; Alemayehu, Z.; Dachaga, W. Uncovering Land Tenure Insecurities: Tips for Tenure Responsive Land-Use Planning in Ethiopia. Dev. Pract. 2019, 29, 371-383. [CrossRef]

28. Chigbu, U.E.; Ntihinyurwa, P.D.; Vries WT d Ngenzi, E.I. Why Tenure Responsive Land-Use Planning Matters: Insights for Land Use Consolidation for Food Security in Rwanda. Environ. Res. Public Health 2019, 16, 1354. [CrossRef]

29. Chigbu, U.E.; Schopf, A.; Vries WT d Masum, F.; Mabikke, S.; Antonio, D.; Espinoza, J. Combining Land-Use Planning and Tenure Security: A Tenure Responsive Land-Use Planning Approach for Developing Countries. J. Environ. Plan. Manag. 2017, 60, 1622-1639. [CrossRef]

30. Garcia-Martin, M.; Torralba, M.; Quintas-Soriano, C. Linking Food Systems and Landscape Sustainability in the Mediterranean Region. Landsc. Ecol. 2020, 1-7. [CrossRef]

31. Bernardo, F.; Rodrigues, A.; Branquinho, C.; Garcia, P. Elemental profile of native lichens displaying the impact by agricultural and artificial land uses in the Atlantic island of São Miguel (Azores). Chemosphere 2020, 128887. [CrossRef]

32. Kazmierczyk, P.; Reichel, A.; Bakas, I.; Isoard, S.; Kristensen, P.; Werner, B.; Jol, A.; Kurnik, B.; Fogh Mortensen, L.; Ribeiro, T.; et al. The European Environment-State and Outlook 2010. Land Use [Bind 9]; European Environment Agency: Copenhagen, Denmark, 2010.

33. Dunk A von der Grêt-Regamey, A.; Dalang, T.; Hersperger, A.M. Defining a Typology of Peri-Urban Land-Use Conflicts-A Case Study from Switzerland. Landsc. Urban Plan. 2011, 101, 149-156. [CrossRef]

34. Kaswamila, A.L.; Songorwa, A.N. Participatory Land-Use Planning and Conservation in Northern Tanzania Rangelands. Afr. J. Ecol. 2009, 47, 128-134. [CrossRef]

35. Atmo, G.U.; Duffield, C.; Zhang, L.; Wilson, D.I. Comparative Performance of PPPs and Traditional Procurement Projects in Indonesia. Int. J. Public Sect. Manag. 2017, 30, 118-136. [CrossRef]

36. Didik, H.; Bambang, P.N.; Asep, S.; Purwanto, Y.A. Sustainability Challenge of Micro Hydro Power Development in Indonesia. IOP Conf. Ser. Earth Environ. Sci. 2018, 147, 012031. [CrossRef]

37. Douglas, M. Globalization, Mega-projects and the Environment. Urban Form and Water in Jakarta. Environ. Urban. ASIA 2010, 1, 45-65. [CrossRef] 
38. Frazila, R.B.; Zukhruf, F.; Burhani, J.T. Developing a Probabilistic Model of Constructing Seaport Hinterland Boundaries. IOP Conf. Ser. Earth Environ. Sci. 2018, 158, 012023. [CrossRef]

39. Mahani, I.; Tamin, R.Z.; Pribadi, K.S.; Wibowo, A. The Risk of Construction Grant Support in Toll Road Investment Faced by Indonesia's Government. MATEC Web Conf. 2019, 270, 05001. [CrossRef]

40. Malisan, J. Port of Patimban as a Solution to Fulfil the Capacity Demand of Port Terminal in Indonesia. Int. J. Innov. Eng. Technol. 2017, 8, 303-310.

41. Mittal, J.; Kashyap, A. Real Estate Market Led Land Development Strategies for Regional Economic Corridors-A Tale of Two Mega Projects. Habitat Int. 2015, 47, 205-217. [CrossRef]

42. Ardiyono, S.K.; Parenrengi, N.P.A.; Faturachman, F. How does Toll Road Impact Accessibilities, Trades, and Investments in Short Term? A Case Study of Cipali Toll Road in West Java, Indonesia. J. Infrastruct. Policy Dev. 2018, 2, 226-247. [CrossRef]

43. Notteboom, T.E.; Rodrigue, J.-P. Port Regionalization: Towards a New Phase in Port Development. Marit. Policy Manag. 2005, 32, 297-313. [CrossRef]

44. Leisch, H. Gated Communities in Indonesia. Cities 2002, 19, 341-350. [CrossRef]

45. Jung, B.-M. Economic Contribution of Ports to the Local Economies in Korea. Asian J. Shipp. Logist. 2011, 27, 1-30. [CrossRef]

46. Huang, W.-C.; Chen, C.-H.; Kao, S.-K.; Chen, K.-Y. The Concept of Diverse Developments in Port Cities. Ocean. Coast. Manag. 2011, 54, 381-390. [CrossRef]

47. Taylor, M. Community Participation in the Real World: Opportunities and Pitfalls in New Governance Spaces. Urban Stud. 2007, 44, 297-317. [CrossRef]

48. Butler, C.; Adamowski, J. Empowering marginalized communities in water resources management: Addressing inequitable practices in Participatory Model Building. J. Environ. Manag. 2015, 153, 153-162. [CrossRef] [PubMed]

49. Firman, T. Land Conversion and Urban Development in the Northern Region of West Java, Indonesia. Urban Stud. 1997, 34, 1027-1046. [CrossRef]

50. Firman, T. Rural to Urban Land Conversion in Indonesia during Boom and Bust Period. Land Use Policy 2000, 17, 13-20. [CrossRef]

51. Firman, T. The Continuity and Change in Mega-Urbanization in Indonesia: A Survey of Jakarta-Bandung Region (JBR) Development. Habitat Int. 2009, 33, 327-339. [CrossRef]

52. Permatasari, P.A.; Fatikhunnada, A.; Liyantono Setiawan, Y.; Syartinilia; Nurdiana, A. Analysis of Agricultural Land Use Changes in Jombang Regency, East Java, Indonesia Using BFAST Method. Procedia Environ. Sci. 2016, 33, 27-35. [CrossRef]

53. Reerink, G. Tenure Security for Indonesia's Urban Poor. A Socio-Legal Study on Land, Decentralisation, and the Rule of law in Bandung; Leiden University Press: Leiden, The Netherlands, 2011.

54. Sahide, M.A.K.; Giessen, L. The Fragmented Land Use Administration in Indonesia-Analysing Bureaucratic Responsibilities Influencing Tropical Rainforest Transformation Systems. Land Use Policy 2015, 43, 96-110. [CrossRef]

55. Riggs, R.A.; Sayer, J.; Margules, C.; Boedhihartono, A.K.; Langston, J.D.; Sutanto, H. Forest Tenure and Conflict in Indonesia: Contested Rights in Rempek Village, Lombok. Land Use Policy 2016, 57, 241-249. [CrossRef]

56. Bakker, L.; Moniaga, S. The Space Between: Land Claims and the Law in Indonesia. Asian J. Soc. Sci. 2010, 38, 187-203. [CrossRef]

57. Payne, G. Land Tenure and Property Rights: An Introduction. Habitat Int. 2004, 28, 167-179. [CrossRef]

58. Reerink, G.; van Gelder, J.-L. Land Titling, Perceived Tenure Security, and Housing Consolidation in the Kampongs of Bandung, Indonesia. Habitat Int. 2010, 34, 78-85. [CrossRef]

59. Sabir, M.; Torre, A.; Magsi, H. Land-Use Conflicts and Socio-economic Impacts of Infrastructure Projects: The Case of Diamer Bhasha Dam in Pakistan. Area Dev. Policy 2017, 2, 40-54. [CrossRef]

60. Ardiwijaya, V.S.; Sumardi, T.P.; Suganda, E.; Temenggung, Y.A. Rejuvenating Idle Land to Sustain Urban Form: Case Study of Bandung Metropolitan Area, Indonesia. Procedia Environ. Sci. 2015, 28, 176-184. [CrossRef]

61. BPS Kabupaten Subang. Available online: https://subangkab.bps.go.id/publication/2019/08/16/94f76338bddfaf2d68e647c4 / kabupaten-subang-dalam-angka-2019.html (accessed on 8 August 2020).

62. DPMPTSP Jawa Barat. Available online: https://dpmptsp.jabarprov.go.id/web/pages/detail/253-realisasi-investasi-pma-danpmdn-se-jawa-barat-januari-maret-tahun-2017/293/298/300 (accessed on 14 July 2020).

63. BPS Kabupaten Subang. Available online: https://subangkab.bps.go.id/publication/2018/08/16/fbf586fd952afd9aa9db7052/ kabupaten-subang-dalam-angka-2018.html (accessed on 10 August 2020).

64. Ministry of Transportation of the Republic of Indonesia. Interviewed in October 2018.

65. Pemerintah Kabupaten Subang. Rencana Tata Ruang Wilayah (RTRW) Kabupaten Subang Tahun 2011-2031 (Revisi); Pemerintah Kabupaten Subang: Subang, Indonesia, 2019.

66. Pemerintah Kabupaten Subang. Rencana Tata Ruang Wilayah (RTRW) Kabupaten Subang Tahun 2011-2031; Pemerintah Kabupaten Subang: Subang, Indonesia, 2014.

67. Regional Development Planning Board of Subang Regency (BAPPEDA). Interviewed in October 2018.

68. Pemerintah Kabupaten Subang. Rencana Pembangunan Jangka Menengah Daerah (RPJMD) Kabupaten Subang Tahun 2009-2014; Pemerintah Kabupaten Subang: Subang, Indonesia, 2009.

69. Regional Development Planning Board of West Java Province (BAPPEDA). Interviewed in October 2018.

70. JICA. Available online: https://www.jica.go.jp/english/our_work/social_environmental/id/asia/southeast/indonesia/c8h0 vm00009ylvi7.html (accessed on 12 September 2019). 
71. Pemerintah Republik Indonesia. Rencana Tata Ruang Nasional Tahun (RTRWN) 2008-2028 (Revisi); Pemerintah Republik Indonesia: Jakarta, Indonesia, 2015.

72. Indonesia.Go.Id. Available online: https://indonesia.go.id/narasi/indonesia-dalam-angka/ekonomi/dari-cikarang-lewatpatimban-ke-pasar-dunia (accessed on 14 February 2020).

73. Republik Indonesia. Penetapan Pelabuhan Patimban di Kabupaten Subang Provinsi Jawa Barat Sebagai Proyek Strategis Nasional. In Peraturan Presiden Republik Indonesia, Nomor 47 Tahun 2016; Republik Indonesia: Jakarta, Indonesia, 2016.

74. Bandung Institute of Technology. Interviewed in November 2018.

75. Transportation Board of West Java Province. Interviewed in October 2018.

76. Pemerintah Provinsi Jawa Barat. Rencana Pembangunan Jangka Menengah Daerah (RPJMD) Provinsi Jawa Barat Tahun 2018-2023; Pemerintah Provinsi Jawa Barat: Bandung, Indonesia, 2019.

77. Pemerintah Provinsi Jawa Barat. Rencana Tata Ruang Wilayah (RTRW) Provinsi Jawa Barat Tahun 2009-2029; Pemerintah Provinsi Jawa Barat: Bandung, Indonesia, 2010.

78. DiCicco-Bloom, B.; Crabtree, B.F. The Qualitative Research Interview. Med. Educ. 2006, 40, 314-321. [CrossRef]

79. Robert, W. Book Review: Corbin, J., strauss, A. Basics of Qualitative Research: Techniques and Procedures for Developing Grounded Theory (3rd Ed.); SAGE: Thousand Oaks, CA. Organ. Res. Methods 2008, 12, 614-617.

80. Brinkmann, S.; Kvale, S. InterViews: Learning the Craft of Qualitative Research Interviewing, 3rd ed.; SAGE Publications: Los Angeles, LA, USA, 2015.

81. Susman, R.; Gütte, A.M.; Weith, T. Annex: Structure of Interview. (unpublished). Available online: http:/ / www.nzdl.org/cgibin/library?e=d-00000-00---off-0cdl--00-0----0-10-0---0---0direct-10---4-------0-11--11-en-50---20-about---00-0-1-00-0--4----00-11-10-0utfZz-8-00\&cl=CL1.45\&d=HASH01dfaa6f0fa3b778e15bdb0d.16\&gt=1 (accessed on 4 October 2020).

82. Pemerintah Republik Indonesia. Undang-Undang Nomor 32 Tahun 2004 tentang Pemerintah Daerah; Pemerintah Republik Indonesia: Jakarta, Indonesia, 2004.

83. Pemerintah Republik Indonesia. Undang-Undang Nomor 25 Tahun 2007 tentang Penanaman Modal; Pemerintah Republik Indonesia: Jakarta, Indonesia, 2007.

84. Pemerintah Republik Indonesia. Undang-Undang Nomor 26 Tahun 2007 tentang Penataan Ruang; Pemerintah Republik Indonesia: Jakarta, Indonesia, 2007.

85. Pemerintah Republik Indonesia. Peraturan Menteri Agraria Tata Ruang/BPN Nomor 14 Tahun 2018 tentang Izin Lokasi; Pemerintah Republik Indonesia: Jakarta, Indonesia, 2018.

86. Pemerintah Republik Indonesia. Peraturan Menteri Pekerjaan Umum Nomor 24 Tahun 2007 tentang Pedoman Teknis Izin Mendirikan Bangunan Gedung; Pemerintah Republik Indonesia: Jakarta, Indonesia, 2007.

87. Pemerintah Republik Indonesia. Undang-Undang Nomor 25 Tahun 2004 tentang Sistem Perencanaan Pembangunan Nasional; Pemerintah Republik Indonesia: Jakarta, Indonesia, 2004.

88. AKSI Subang. Interviewed in October 2018.

89. Subang University. Interviewed in October 2018.

90. Government of Patimban Village. Interviewed in November 2018.

91. Farmers and land owners in Patimban Village. Interviewed in November 2018.

92. Pemerintah Provinsi Jawa Barat. Rencana Tata Ruang Wilayah (RTRW) Provinsi Jawa Barat Tahun 2009-2029 (revisi); Pemerintah Provinsi Jawa Barat: Bandung, Indonesia, 2019.

93. CNBC Indonesia. Available online: https://www.cnbcindonesia.com/news/20190116190712-4-51011/target-operasi-2019-apakabar-proyek-pelabuhan-patimban (accessed on 4 February 2021).

94. Pasundan Ekspres. Available online: https://www.pasundanekspres.co/jabar/subang/saluran-air-tersendat-petani-mintaksop-patimban-tanggungjawab / (accessed on 4 October 2020).

95. Detik Finance. Available online: https:// finance.detik.com/infrastruktur/d-4802384/jalan-akses-pelabuhan-patimban-sudah-55 -bisa-rampung-2020 (accessed on 4 October 2020).

96. Hui, E.C.M.; Bao, H. The Logic behind Conflicts in Land Acquisitions in contemporary China: A Framework Based upon Game Theory. Land Use Policy 2013, 30, 373-380. [CrossRef]

97. JICA. Available online: https://www.jica.go.jp/english/our_work/social_environmental/id/asia/southeast/indonesia/c8h0 vm00009ylvi7-att/c8h0vm0000b1ppnx.pdf (accessed on 8 July 2020).

98. Fishermen in Patimban Village. Interviewed in November 2018.

99. Land cultivators in Patimban Village. Interviewed in November 2018.

100. Fürst, C. Upcoming Challenges in Land Use Science-An International Perspective. In Sustainable Land Management in a European Context-A Co-Design Approach; Weith, T.H., Barkmann, T., Gaasch, N., Rogga, S., Strauß, C.H., Zscheischler, J., Eds.; Springer: Berlin, Germany, 2021; pp. 319-336.

101. Weigelt, J.; Müller, A.; Janetschek, H.; Töpfer, K. Land and soil governance towards a transformational post-2015 Development Agenda: An overview. Curr. Opin. Environ. Sustain. 2015, 15, 57-65. [CrossRef]

102. Rydin, Y. Re-examining the Role of Knowledge within Planning Theory. Plan. Theory 2007, 6, 52-68. [CrossRef]

103. Salet, W. The Authenticity of Spatial Planning Knowledge. Eur. Plan. Stud. 2014, 22, 293-305. [CrossRef]

104. Swyngedouw, E. Governance innovation and the citizens: The Janus face of governance-beyond-the-state. Urban Stud. 2005, 42, 1991-2006. [CrossRef] 
105. Lange, P.; Driessen, P.; Sauer, A.; Bornemann, B.; Burger, P. Governing Towards Sustainability-Conceptualizing Modes of Governance. J. Environ. Policy Plan. 2013, 15, 403-425. [CrossRef]

106. Weith, T.H.; Barkmann, T.; Gaasch, N.; Rogga, S.; Strauß, C.H.; Zscheischler, J. Conclusions and Research Perspectives. In Sustainable Land Management in a European Context-A Co-Design Approach; Weith, T.H., Barkmann, T., Gaasch, N., Rogga, S., Strauß, C.H., Zscheischler, J., Eds.; Springer: Berlin, Germany, 2021; pp. 339-347.

107. Friis, C. A New Framework for Researching Land-Use Change in a Globalised World. In Telecoupling; Friis, C., Nielsen, J.Ø., Eds.; Springer International Publishing: Berlin, Germany, 2019; pp. 49-67.

108. Liu, J.; Herzberger, A.; Kaspar, K.; Carlson, A.; Connor, T. What is Telecoupling? In Telecoupling; Friis, C., Nielsen, J.Ø., Eds.; Springer International Publishing: Berlin, Germany, 2019; pp. 19-48. 